\title{
Emotions and Cognitions When Reading Online Reviews: Effect on Tourism Service Image
}

\author{
Carmen Hidalgo-Alcazar ${ }^{*}$, Salvador Ruiz², Maria Sicilia ${ }^{2}$
}

\begin{abstract}
The purpose of this study is to examine how online reviews from other users in a tourism service website generate emotions and cognitions that contribute to the formation of the image of a tourism service. We used a real website of a rural destination as a tourism service. We tested the proposed conceptual model using structural equation modeling. Our results show a correspondence between consumers' thoughts and the cognitive dimension of image, as well as between the emotions expressed by subjects and the affective dimension of image. Results confirm that the image of a tourism service is an important predictor of tourism service preferences. This overall image influences consumers' future intentions, not only to buy the service but also to recommend it to other consumers. In summary, we propose and test a model that shows how online reviews significantly influence image formation and subsequent consumer behaviors. To date, little is known about to what extent online reviews are useful to generate cognitive and emotional responses in potential tourists. Consequently, understanding its role in a tourist's decision making process, and assessing the relationships between utility of online reviews, emotions, cognitions and image towards the tourism service will make both scientific and practical contributions. While contributing to the body of knowledge on image formation process, our results are also relevant for public administrations and tourism marketing managers.
\end{abstract}

Keywords: Online Reviews, Emotions, Cognitions, Tourism Service, Image.

Submitted: January 22 $2^{\text {nd }}, 2021 /$ Approved: December $3^{\text {rd }}, 2021$

\section{Introduction}

Imagine that you are planning to visit a specific destination and need to book a tourism service in that area. You could ask friends, check out a travel agency, or search on the Internet. Nowadays, a great deal of interesting and relevant content can be found online, including reviews that can be considered as part of travel planning (Narangajavana et al., 2017; Xiang et al., 2015). Many online resources enable potential tourists to search for possible destinations, transportation, accommodation, and leisure activities, as well as to purchase these services (Hajli, 2014). Among these resources, online reviews have become critical, with hundreds of millions of potential visitors consulting them every year. Travellers across the globe use the TripAdvisor site to browse more than 760 million reviews and opinions of 8.3 million accommodations, restaurants, experiences, airlines and cruises (Tripadvisor, 2018). Therein, travellers share their experiences and emotions to help potential tourists to form an impression of tourism services, as well as contributing to the development of the service's image.

Previous research has shown that online browsing influences both the cognitive and the affective dimensions of image, although most such research has focused on the cognitive component alone (Bigné et al., 2009). However, the influence of online reviews on image is yet to be fully revealed (Jani \& Hwang, 2011). To the best of our knowledge, the effect of online reviews on the emotional and cognitive responses evoked by potential tourists is mostly unknown. Many studies have claimed that emotional responses are involved in communication processes (Allen et al., 2005; Pestana et al., 2019; Hosany \& Gilbert,
2010; Prayag et al., 2017), but extant research has failed to combine both cognitions and emotions in a holistic communication model. This paper aims to contribute to this underexplored area in the literature of tourism service image. We examine the bi-dimensional nature of overall image, in terms of its emotional and cognitive components, as well as its effect on behavioural intentions (purchase and recommendation). A theoretical model that relates emotional and cognitive consequences of online reviews with the image of a tourism service is proposed. Results of the study are discussed in light of previous studies' findings, and implications and recommendations for future research are presented at the end of the paper.

\section{Literature review and hypotheses}

The Perceived Usefulness of Online Reviews in Tourism. Online reviews (recommendations and experience sharing) are a valuable source of 'real-time' information on consumer attitudes (Ye et al., 2009). Analysing opinions allows capturing both modified holistic images held by experienced tourists and baseline images held by potential tourists (Jani \& Hwang, 2011). Liu et al (2011) identified four objectives of online consumer reviews: (1) to assist consumers in making accurate choices, (2) to reduce the cognitive costs of making such choices, (3) to help consumers form an unbiased understanding of the product, and (4) to construct a set of evaluative criteria. Online consumer reviews are heavily relied on by potential tourists in forming images of tourism services, since the previous quality of these services cannot be ascertained otherwise, due to their experiential nature (Cox et al., 2009).

(1) University of León, Faculty of Economic and Management Sciences, León, Spain

(2) University of Murcia, Marketing Department, Murcia, Spain

*Corresponding author: mhida@unileon.es 
Previous studies have shown that online reviews influence travellers' decisions (Abubakar \& Ilkan, 2016; Vermeulen \& Seegers, 2009) and trip-planning processes (Gretzel \& Yoo, 2008; Mendes-Filho et al., 2018). However, the degree of influence of online reviews in the tourism industry is still largely unknown to either tourism researchers or practitioners (Chong et al., 2018; Liu \& Park, 2015).

Before they have an impact on decisions, online reviews may lead the potential tourist to develop cognitive and emotional responses. In parallel to what has been found in marketing communications literature (Batra \& Ray, 1986), information from online reviews will help the receiver develop cognitive and emotional responses towards the tourism service. Consumers' access to information related to attributes, experiences, and feelings shared by other tourists might help them to form an impression about the tourism service (Jani \& Hwang, 2011).

Given its importance as an information source (Ye et al., 2009), the more useful online reviews are for the potential tourist, the more responses can be expected, as the tourist will dedicate more resources to processing this information (Papathanassis \& Knolle, 2011). Therefore, based on the perceived usefulness of online review information (Casaló et al., 2015), potential tourists will generate more favourable cognitions and emotions related to the tourism service. Thus, we propose the following hypotheses:

H1: Perceived usefulness of online reviews related to a tourism service increases the favourableness of the cognitions evoked.

$\mathrm{H} 2$ : Perceived usefulness of online reviews related to a tourism service increases the favourableness of the emotions evoked.

Tourism Service Image: The Role of Emotions and Cognitions. Image has been one of the most explored concepts in tourism research (Chen, 2001). It is composed of two dimensions: cognitive and affective (Crompton, 1979). However, except for some exceptions (Baloglu \& McCleary, 1999; Mackay \& Fesenmaier, 2000), most image studies have focused exclusively on the cognitive dimension (Leisen, 2001). Evaluation of affective qualities might become even more important than objective, perceptible properties of tourism services (Kim \& Richardson, 2003). Only recently, several studies (Moreno-Gil \& Martín-Santana, 2015; Papadimitriou et al., 2018) have highlighted the cognitive-affective nature of image, pointing out that it is integrated not only by the individual's cognitive evaluations, but also their affective evaluations (Kim \& Richardson, 2003; Pike \& Ryan, 2004). The coexistence of both components may better explain the image tourists have of a tourism service (Baloglu \& Brinberg, 1997; Marinao et al., 2012).

Emotions are now recognized to play a critical role in the consumption experience (Prayag et al., 2013). Zajonc (1980) challenged researchers to consider more than cognition in their attempts to understand human behaviour, while Holbrook and Hirschman (1982) led the charge to take into account consumers' 'feelings, fantasies, and fun' as part of the overall consumption experience. The inclusion of emotions into a theoretical framework is particularly critical for experiential services (Bigné et al., 2008; Mattila \& Enz, 2002; Prayag et al., 2017).
As suggested by Batra and Ahtola (1991, p. 159), "consumers purchase goods and services and perform consumption behaviour for two basic reasons: (a) consummatory affective (hedonic) gratification (from sensory attributes), and (b) instrumental, utilitarian reasons." Previous studies have suggested that hospitality and tourism services are likely to be high in both (Batra \& Ahtola, 1991; Voss et al., 2003).

Voss et al. (2003) conceptualized the hedonic and utilitarian constructs as dimensions of the brand attitude concept. The hedonic dimension of a consumption experience can be derived from a product's uniqueness, symbolic meaning, or the emotional arousal and imagery it evokes (Holbrook and Hirschman, 1982). In contrast, the utilitarian dimension is associated with products or services that are instrumental in fulfilling functional goals.

The affective evaluation of image, also known as the hedonic dimension (Batra \& Ahtola, 1991), is associated with the emotions generated by the stimulus, while the cognitive evaluation or utilitarian dimension is related to the consumer's beliefs and perceived attributes. In the tourism context, the utilitarian dimension of a tourism service image will be based on the beliefs the consumer has of the attributes of that tourism service (Pike \& Ryan, 2004), while the hedonic dimension will be based on the tourist's feelings towards the tourism service (Kim \& Richardson, 2003).

Thus, in an attempt to reach a more favourable image, individuals who produce a higher number of emotions will generate a more favourable hedonic dimension of image. Similarly, individuals who produce a higher number of cognitions will generate a more favourable utilitarian dimension of image. Therefore, in a tourism context, the number of cognitions and emotions generated through consumers' exposure to online reviews will directly impact the utilitarian and hedonic dimensions of the tourism service's image. Formally, we propose the following hypotheses:

H3: Favourableness of emotions influences the hedonic dimension of image of the related tourism service.

$\mathrm{H} 4$ : Favourableness of cognitions influences the utilitarian dimension of image of the related tourism service.

The Relationship between the Image Dimensions of a Tourism Service. The distinction and direction of the relationship between cognitive and affective components have been discussed in several tourism decision-making models (Baloglu \& McCleary, 1999; Lin et al., 2007). The findings show that both cognitive and affective evaluations exert a direct impact on overall image. Several studies have included cognitive and affective attributes in the measurement of image (Papadimitriou et al., 2018; Moreno-Gil \& Martín-Santana, 2015; Wang \& Hsu, 2010).

As stated by Gartner (1993), people's perceptions of various attributes interact to form an overall image. The combination of cognitive and affective evaluations gives rise to an overall or composite image that is greater than the sum of its parts (Calantone et al., 1989). Ahmed (1991) suggested that the evaluation of the overall image and its two main components should all be considered and assessed. Indeed, the 
overall image has been considered a third component of the image, which may be similar to, or different from, the cognitive or affective perceptions of the tourism service (Baloglu \& McCleary, 1999; Gartner, 1993). In line with this research vein, tourism service image should be considered a multi-dimensional phenomenon that includes not only beliefs about the service attributes, but also feelings towards the tourism service. Consequently, we propose that the utilitarian and hedonic dimensions of a tourism service image are positively related to the overall image of the tourism service. We thus derive the following hypotheses:

H5: The hedonic dimension of image of a tourism service positively influences the service's overall image.

H6: The utilitarian dimension of image of a tourism service positively influences the service's overall image.

In the past, image literature showed that the cognitive evaluation had an indirect influence on the overall image through the affective evaluation (Baloglu \& McCleary, 1999; Beerli \& Martin, 2004; Lin et al., 2007). Consumer behaviour literature seems to support the opposite. For example, Coulter (1998) found a direct link between feelings and cognitions, while Pham et al. (2001) later showed that feelings could guide and, consequently, predict thoughts. They argued that once feelings have been registered, the initial affective response will lead to subsequent thought generation through automatic and controlled processes. Therefore, the initial affective response will lead the subject to retrieve congruent material through this affect (Blaney, 1986). This process will lead to a more elaborate, relevant, and, in short, cognitive response (Cohen \& Areni, 1991). Additionally, López and Ruiz (2011) demonstrated that emotions exert a direct influence on thoughts, while the impact of the former on attitude flows both directly and indirectly through cognitions. These recent results provide strong support for the intervening role of affective evaluation on cognitive evaluations. Managerial practices in tourism also support the relevance of affective evaluation, since companies are becoming increasingly focused on engaging consumers in affective experiences. On the basis of previous literature and recent managerial practices, we propose the following hypothesis:

H7: The hedonic dimension of image of a tourism service positively influences its utilitarian dimension.

Image and Tourist Behaviours. Tourism image is an important issue that affects the way in which tourists make decisions regarding their choice of destination (Camprubi et al., 2014). While tourist behaviours include the choice of a tourism service and subsequent evaluations including recommendations (Kneesel et al, 2010), behavioural intentions such as intention to purchase and to recommend have become a basic metrics to evaluate the success of a tourism service (Kneesel et al., 2010; Qu et al., 2011; Wang \& Hsu, 2010).

Literature has shown that the overall image of a tourism service is influential not only for the selection process itself (Baloglu \& McCleary, 1999), but also for tourist behaviour in general (Bigné et al., 2001). For example, Lee et al. (2005) argued that individuals' favourable ima- ge will lead to greater levels of behavioural intentions. Thus, we expect that if a person holds a positive overall image of a particular tourism service, he/she will be more likely to purchase that service. Thus, we can derive the following hypothesis:

H8: The overall image of a tourism service positively influences the intention to purchase the tourism service.

Previous research has shown that overall image may condition afterdecision-making behaviours, including the willingness to recommend (Bigné et al., 2001; Lee et al., 2005). The more positive the overall image of a destination perceived by a tourist, the greater the likelihood that the tourist will recommend it to other potential tourists, such as friends and relatives (Zhang et al., 2014). Therefore, research has established a positive influence of overall image on tourists' intention to recommend. Bigné et al. (2001) empirically showed that overall image is a direct antecedent of intention to recommend a destination following purchase. We thus expect that the more positive the image of a tourism service, the more likely it is that the tourist will recommend the service to others (e. g. face to face, or via online reviews or chats). Therefore, we propose the following hypothesis:

H9: The overall image of a tourism service positively influences the tourist's intention to recommend it.

\section{Research method}

Design and procedure. We used a real website of a rural destination as a contextual stimulus in this study. The selection of rural tourism services was motivated by the fact that image formation process mainly occurs through destination websites in this type of small touristic services. The expansion of rural tourism explains the growing number of academic papers published in this field (Herrero \& San Martín, 2012; Lanfranchi et al., 2014; Hidalgo-Alcázar et al., 2015). In addition, rural tourism is one of the most active sectors on the Internet. Currently, it is the main medium through which 8 out of 10 rural travelers (83.79\%) looking for accommodation organize their trip when selecting rural tourism. Following previous research (Mulpuru et al., 2007), the website included info about the destination area and the accommodation, and a section containing positive online reviews. In Spain, more than $96 \%$ of travelers say they read others' online reviews before choose rural accommodation because it helps them make a decision and $58.4 \%$ always leave a rating after their stay (Clubrural, 2021). The perceived usefulness of online reviews seems to be well represented in this context.

A sample of students was recruited through advertisements located at different points of a Spanish university. A gift was offered in reward for completing the questionnaire. The survey population consisted of individuals with no previous knowledge about the tourism service used in the study. We collected 242 valid questionnaires. The sample average age was 22 (ranging from 18 to 28 ) and 51.7\% were women. The main dependent variables, such as overall image and intention to purchase and recommend the tourism service, were not significantly affected by these variables. 
Students are considered ideal samples for testing theoretical predictions about the relationships among variables (Calder et al., 1981), which is in line with the purpose of this study. Singh et al. (2000) also suggested that the effects of advertising on students and the public are the same. In addition, student samples have been used frequently in marketing (Keh \& Pang, 2010) and tourism studies (Lee \& Gretzel, 2012).

On arrival at the computer lab, the subjects were informed about the procedure and instructed to freely navigate the rural accommodation website, as if they were looking to book a weekend trip. After website exposure, the individuals answered questions concerning the variables included in the proposed model. We also asked participants whether they had accessed the online reviews section during website exposure. A total of 160 individuals (66.1\%) indicated that they had accessed the online reviews generated by other users. Since our independent variable is perceived usefulness of online reviews, the results reported here include only the 160 individuals who accessed those reviews. This procedure ensured a more realistic and natural setting, as individuals were not forced to read the online reviews.

Encoding of Emotions and Cognitions. Following previous literature (López \& Ruiz, 2011; Sicilia et al., 2005), the participants wrote down all the thoughts that came into their minds while they were navigating the website. They were then instructed to write down all the emotions they experienced during exposure (Coulter, 1998; López et al., 2007). Through this procedure, the subjects were not forced to make list of specific emotions, but were free to disclose how they felt (Pham et al., 2001).

Two independent judges, unfamiliar with the study objectives, classified the cognitive and emotional responses as positive, negative or neutral. The two judges were very consistent in their classifications. For thought content, the judges agreed 90 percent of the time. As recommended by Rose et al. (1990), a third judge solved disagreements. To facilitate their task, we provided them with a list of 56 feelings from Burke and Edell (1989). As net responses is an approximation to the level of cognitive and emotional persuasion of the individual (Campbell \& Keller, 2003; Rose et al., 1990; Sicilia et al., 2005), favourableness of emotions/cognitions was calculated by subtracting the number of unfavourable responses from the number of favourable ones (Campbell \& Keller, 2003). Neutral responses were not considered in the calculation.
Measurement Scales. In order to ensure content validity, items for the other constructs were primarily obtained from prior studies in the tourism context, and were included in the questionnaire using 10-point scales. Affective image was measured through Russel's (1980) four bipolar affective items: 'pleasant/unpleasant,' 'relaxing/ distressing,' 'arousing/sleepy', and 'exciting/gloomy' (Baloglu \& McCleary, 1999), while for the cognitive image we used the most applicable items of Ong and Horbunluekit's (1997) scale (Ekinci \& Hosany, 2006): 'isolated/accessible,' 'unfriendly/friendly', 'dirty/clean,' 'quiet/ noisy,' and 'unsafe/safe.' The respondents were also asked to rate their overall image of the tourism service using three bipolar items: 'unfavourable/favourable, 'bad/good,' 'negative/positive' (Baloglu \& McCleary, 1999). Behavioural intentions were measured through four items adapted from Kneesel et al. (2010) related to recommendation and booking the tourism service. Perceived usefulness of online reviews included four items, such as 'These reviews allow me to get an idea of this tourism service’ (Gilly et al., 1998).

A favourable attitude toward using online reviews is more likely to encourage travellers to use these reviews when making travel plans (Mendes-Filho et al., 2012). Therefore, we included a measure of the general attitude towards reviews, which allowed us to control for this potential confounding effect (Park et al., 2007). Finally, the questionnaire asked for respondents' gender, age, and city of residence.

\section{Results}

Reliability, and convergent and discriminant validity of the measurement instrument. A confirmatory factor analysis (CFA) containing all the multi-item constructs in our framework was estimated with Structural Equation Modelling (EQS) (Bentler, 2005) using the maximum likelihood method. Raw data screening showed evidence of non-normal distribution (Mardia's coefficient normalized estimate $=40.3$ ), and the recommendation of $\mathrm{Hu}$ et al. (1992) of correcting the statistics was followed in this study. We, therefore report robust statistics (Satorra \& Bentler, 1988).

An initial CFA led to the deletion of two items related to the cognitive image dimension ('isolated/accessible' and 'unfriendly/friendly') based on low loading estimates (below .60), patterns of residuals, and Lagrange multiplier tests (Anderson \& Gerbing, 1988). The results of the final CFA (Table 1) provide a good fit to the data (S-B $(\mathrm{df}=216)=300.95, \mathrm{p}<.01 ; \mathrm{NNFI}=.90 ; \mathrm{CFI}=.92 ; \mathrm{IFI}=.92 ; \mathrm{RMSEA}=.050)$, evidence of convergent validity (Hair et al, 1998), and show high internal consistency of the constructs (Fornell \& Larcker, 1981). 
Table 1: Internal consistency and convergent validity of the theoretical construct measures

\begin{tabular}{|c|c|c|c|c|c|c|c|}
\hline Variable & Indicator & Factor loading & $\begin{array}{l}\text { Robust } \\
\text { t-value }\end{array}$ & Loading average & CA & CR & AVE \\
\hline \multirow{5}{*}{ Perceived usefulness of online reviews } & OR1 & $.841^{\star *}$ & 8.806 & \multirow{5}{*}{.823} & \multirow{5}{*}{.894} & \multirow{5}{*}{.894} & \multirow{5}{*}{.678} \\
\hline & OR2 & $.823^{\star *}$ & 7.951 & & & & \\
\hline & OR3 & $.779^{* *}$ & 8.501 & & & & \\
\hline & OR4 & $.850^{\star *}$ & 9.484 & & & & \\
\hline & UD3 & $.806^{\star *}$ & 5.533 & & & & \\
\hline \multirow[t]{2}{*}{ Utilitarian dimension of image } & UD4 & $.644^{\star *}$ & 2.988 & \multirow[t]{2}{*}{.730} & \multirow[t]{2}{*}{.768} & \multirow[t]{2}{*}{.775} & \multirow[t]{2}{*}{.537} \\
\hline & UD5 & $.739^{* *}$ & 10.125 & & & & \\
\hline \multirow{5}{*}{ Hedonic dimension of image } & HD1 & $.779^{* *}$ & 5.386 & \multirow{5}{*}{.773} & \multirow{5}{*}{.842} & \multirow{5}{*}{.856} & \multirow{5}{*}{.600} \\
\hline & $\mathrm{HD} 2$ & $.683^{\star *}$ & 8.289 & & & & \\
\hline & HD3 & $.805^{\star *}$ & 8.742 & & & & \\
\hline & $\mathrm{HD} 4$ & $.823^{\star *}$ & 6.010 & & & & \\
\hline & OI1 & $.868^{\star *}$ & 6.485 & & & & \\
\hline \multirow{3}{*}{$\begin{array}{l}\text { Overall } \\
\text { image }\end{array}$} & OI2 & $.859^{* *}$ & 8.338 & \multirow[t]{2}{*}{.868} & \multirow[t]{2}{*}{.898} & \multirow[t]{2}{*}{.902} & \multirow[t]{2}{*}{.754} \\
\hline & OI3 & $.878^{\star *}$ & 7.099 & & & & \\
\hline & $\mathrm{P} 1$ & $.957^{\star *}$ & 14.073 & \multirow{2}{*}{.952} & \multirow{2}{*}{.950} & \multirow{2}{*}{.950} & \multirow{2}{*}{.905} \\
\hline Purchase intention & $\mathrm{P} 2$ & $.946^{\star *}$ & 13.736 & & & & \\
\hline \multirow{3}{*}{ Intention to recommend } & $\mathrm{R} 1$ & $.964^{\star *}$ & 13.268 & \multirow{2}{*}{.965} & \multirow{2}{*}{.964} & \multirow{2}{*}{.964} & \multirow{2}{*}{.931} \\
\hline & $\mathrm{R} 2$ & $.966^{\star *}$ & 12.333 & & & & \\
\hline & e-WOM1 & $.904^{\star *}$ & 8.785 & \multirow{4}{*}{.809} & \multirow{4}{*}{.867} & \multirow{4}{*}{.885} & \multirow{4}{*}{.660} \\
\hline \multirow{3}{*}{ General attitude toward reviews } & e-WOM2 & $.838^{\star *}$ & 9.295 & & & & \\
\hline & e-WOM3 & $.682^{\star *}$ & 11.302 & & & & \\
\hline & e-WOM4 & $.810^{\star *}$ & 9.984 & & & & \\
\hline
\end{tabular}

Note: The table shows the results of the final confirmatory factor analysis (CFA) that provide a good fit to the data $\mathrm{CFI}=.92 ; \mathrm{IFI}=.92 ; \mathrm{RMSEA}=.050$ ). The total sample is 160 .

$(\mathrm{S}-\mathrm{B}(\mathrm{df}=216)=300.95 ; \mathrm{p}<.01 ; \mathrm{NNFI}=.90 ;$

The meaning of the acronyms used is as follows: $C A=$ Cronbach's alpha; $C R=$ Composite reliability; AVE $=$ Average variance extracted; ${ }^{*} \mathrm{p}<.05,{ }^{*} \mathrm{p}<.01$

Measures used in the study exhibited sufficient evidence of reliability, and convergent and discriminant validity (Table 2) as none of the $95 \%$ confidence intervals (CIs) of the individual elements of the latent fac- tor correlation matrix contained the value of 1.0 (Anderson \& Gerbing, 1988), while the shared variance between pairs of constructs was always lower than the corresponding AVE (Fornell \& Larcker, 1981).

Table 2: Discriminant validity of the theoretical construct measures

\begin{tabular}{|c|c|c|c|c|c|c|c|c|c|}
\hline Construct & Mean & SD & 1 & 2 & 3 & 4 & 5 & 6 & 7 \\
\hline 1. Perceived usefulness of online reviews & 7.81 & 1.67 & .68 & .26 & .32 & .41 & .28 & .31 & .64 \\
\hline 2. Utilitarian dimension of image & 8.64 & 1.25 & {$[.26 ; .77]$} & .54 & .57 & .42 & .19 & .12 & .07 \\
\hline 3. Hedonic dimension of image & 7.88 & 1.40 & {$[.36 ; .78]$} & {$[.63 ; .88]$} & .60 & .49 & .29 & .23 & .12 \\
\hline 4. Overall image & 8.32 & 1.44 & {$[.49 ; .79]$} & {$[.36 ; .94]$} & {$[.44 ; .96]$} & .75 & .53 & .55 & .18 \\
\hline 5. Purchase intention & 6.90 & 2.11 & {$[.38 ; .78]$} & {$[.22 ; .66]$} & {$[.33 ; .74]$} & {$[.62 ; .83]$} & .91 & .57 & .13 \\
\hline 6. Intention to recommend & 7.72 & 2.07 & {$[.40 ; .71]$} & {$[.13 ; .57]$} & {$[.27 ; .69]$} & {$[.63 ; .86]$} & {$[.66 ; .84]$} & .93 & .15 \\
\hline 7. General attitude toward reviews & 7.66 & 1.78 & {$[.71 ; .89]$} & {$[.02 ; .50]$} & {$[.14 ; .57]$} & {$[.19 ; .66]$} & {$[.15 ; .57]$} & {$[.17 ; .59]$} & .66 \\
\hline
\end{tabular}

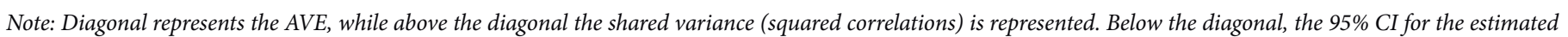
factor correlations is provided.

Descriptive Analysis of Cognitions and Emotions. Overall, 712 cognitive responses and 533 emotional responses were recorded. Table 3 shows averaged values of total (sum of favourable, unfavourable, and neutral responses) and net (difference between favourable and unfavourable) emotions and cognitions. For both emotions and cognitions, favourableness remained at similar levels. 
Table 3: Descriptive analysis of the emotions and cognitions evoked towards the accommodation

\begin{tabular}{lllll}
\hline & \multicolumn{2}{l}{ Cognitions } & Emotions & \\
\cline { 2 - 5 } Favourable & $\mathbf{N}$ & Mean value & $\mathrm{N}$ & Mean value \\
\cline { 2 - 5 } Unfavourable & 602 & 2.49 & 510 & 2.11 \\
Neutral & 46 & 0.19 & 23 & 0.10 \\
TOTAL & 64 & 0.26 & - & - \\
Net & $\mathbf{7 1 2}$ & $\mathbf{2 . 9 4}$ & $\mathbf{5 3 3}$ & $\mathbf{2 . 2 0}$ \\
\hline
\end{tabular}

Note: The table shows averaged values of total (sum of favourable, unfavourable, and neutral responses) and net (difference between favourable and unfavourable) emotions and cognitions. The total sample is 242 .

Test of the Conceptual Model. We tested the proposed conceptual model using structural equation modelling (SEM). The empirical estimates for the main-effects model are shown in Figure 1. The results indicate that the data fit to our conceptual model was acceptable $\left(\mathrm{SBX} X^{2}(\mathrm{df}=258)=383.47, \mathrm{p}<.01 ; \mathrm{NNFI}=.89 ; \mathrm{CFI}=.90 ; \mathrm{IFI}=.90\right.$; RMSEA=.055).

Figure 1: Structural model

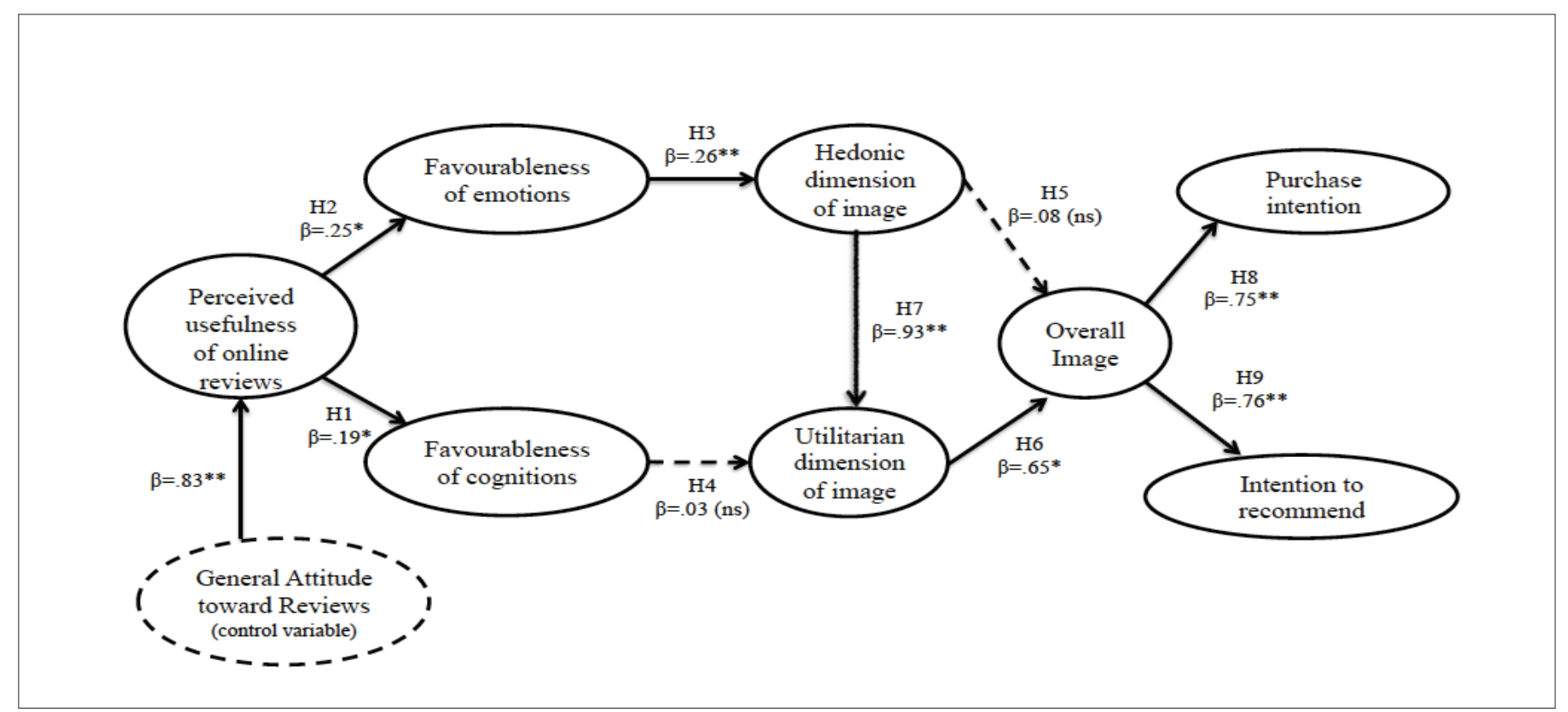

Note: ${ }^{*} \mathrm{p}<.05,{ }^{* *} \mathrm{p}<.01$. The figure shows the results of the hypothesized relationships. The results indicate that the data fit to our conceptual model was acceptable $\left(\mathrm{S}-\mathrm{B} X^{2}(\mathrm{df}=258)=383.47 ; \mathrm{p}<.01 ; \mathrm{NNFI}=.89 ; \mathrm{CFI}=.90 ; \mathrm{IFI}=.90 ; \mathrm{RMSEA}=.055\right)$. The total sample is 160 .

The results of the hypothesized relationships are also reported in Figure 1. Regarding the influence of others' opinions, perceived usefulness of online reviews was able to generate more favourableness in both emotions $(\beta=.19 ; \mathrm{p}<.05)$ and cognitions evoked $(\beta=.25 ; \mathrm{p}<.05)$, after accounting for the variance explained by general attitude toward reviews $(\beta=.83 ; \mathrm{p}<.01)$. These results provide support for both hypotheses $\mathrm{H} 1$ and $\mathrm{H} 2$. We also confirmed the correspondence between the favourableness of emotions and the hedonic dimension of image ( $\beta=.26 ; p<.01)$, but not between the favourableness of cognitions and the utilitarian dimension of image $(\beta=.03 ; \mathrm{p}>.05)$. These results provide support for hypothesis H3, but not for hypothesis H4.

The results also showed that the hedonic dimension of image influenced the utilitarian dimension $(\beta=.93 ; \mathrm{p}<.01)$, but its effect on the overall image $(\beta=.08 ; p>.05)$ was not significant $(\beta=.08 ; p>.05)$. However, the utilitarian dimension of image had an effect on the overall image $(\beta=.65 ; \mathrm{p}<.05)$. These results provide support for hypotheses H6 and H7, but not for hypothesis H5. Finally, the overall image had an impact on both purchase intentions and intention to recommend the tourism service. These results support hypothesis $\mathrm{H} 8(\beta=.75 ; \mathrm{p}<.01)$ and hypothesis $\mathrm{H} 9$ ( $\beta=.76 ; \mathrm{p}<.01)$.

We also checked for the indirect effects using the bootstrap method (Hayes, 2009). As shown in Table 4, the indirect effect through the hedonic and utilitarian dimensions of image is positive and significant $(\beta=.11,[.03 ; .22])$. Therefore, the effect of emotions on overall 
image was mediated through the hedonic and utilitarian dimensions of image. The indirect effect between emotions and the utilitarian dimension of image through the hedonic dimension of image was also significant $(\beta=.19,[.06 ; .33])$, as was the indirect effect between the hedonic dimension and overall image through the utilitarian dimen$\operatorname{sion}(\beta=.36,[.23 ; .50])$.

Table 4: Summary of indirect effects

\begin{tabular}{lllll}
\hline Model & & Estimate & $\begin{array}{l}\text { Bias corrected Bootstrapped } \\
\text { confidence interval }\end{array}$ \\
\hline Ind1: Favourableness of emotions $\rightarrow$ Hedonic dimension $\rightarrow$ Utilitarian dimension & $\rightarrow$ Overall Image & .11 & {$[.03 ; .22]$} \\
Ind2: Favourableness of emotions $\rightarrow$ Hedonic dimension $\rightarrow$ Utilitarian dimension & .19 & {$[.06 ; .33]$} \\
Ind3: Hedonic dimension $\rightarrow$ Utilitarian dimension $\rightarrow$ Overall Image & .36 & {$[.23 ; .50]$} & \\
\hline
\end{tabular}

\section{Conclusion}

Theoretical contributions. Interpersonal communications are an important information source among tourists (Litvin et al., 2008). With the spread of the Internet, virtual interactions among consumers have become commonplace, which has led some tourism researchers to point out that online reviews play an important role in the acquisition and retention of consumers (Vermeulen \& Seegers, 2009; Ye et al., 2011).

One of the main contributions of this paper is demonstrating that online reviews generate cognitive and emotional reactions about tourism services. Although past work has shown that emotions can substantially influence the way reviews are processed (Kim \& Gupta, 2012), it has not addressed considering at the same time emotions and cognitions. Moreover, we show that a link exists between the favourableness of emotions expressed by subjects and the hedonic dimension of image, but not between the favourableness of cognitions and the utilitarian dimension of image. To the best of our knowledge, these links have not been empirically tested before in image literature. Additionally, we contribute to the literature on tourism service image by demonstrating that the utilitarian dimension of image is a significant antecedent of overall image. Tourists will use these image dimensions to form their impressions of, and evaluate, the tourism service in their choice process. Moreover, and contrary to previous research findings (Baloglu \& McCleary, 1999; Qu et al,, 2011), the direct influence of the hedonic dimension of image on overall image is not significant. Instead, we obtain that the hedonic dimension of image influences the utilitarian dimension of image, which, in turn, affects the overall image. Tourists form their beliefs and opinions as a function of their feelings. Our results are consistent with previous findings concerning how affective responses are formed as a function of the cognitive responses (Baloglu \& Brinberg, 1997; Gartner, 1993) and the consequences of overall image in terms of intentions to purchase and recommend the tourism service to others (Bigné et al., 2001; Lee et al., 2005).

Managerial implications. The major findings of this study offer meaningful implications to tourism practitioners in the context of promoting tourism services. First, creating and managing an appropriate image is important for tourism service managers because product trial before consumption is difficult and because a positive image helps to position the tourism service. For that reason, it is necessary to identify the roles of the utilitarian and hedonic components of a tourism service image, in order to accurately implement the most effective positioning strategies (Pike \& Ryan, 2004). Second, managers should encourage consumers to spread the word about their services (Verlegh et al., 2013), as online reviews are an important information source in forming the tourism service image.

In addition, since tourists use hedonic and utilitarian dimensions to form images, the service's positioning strategy should emphasize not only its physical properties (which has been the usual practice up to date), but also the amalgam of emotions that the experience is able to evoke in the tourist's mind. In the first case, the individual's beliefs about the tourism service are reinforced, while in the second the service promotion affects the individual's emotional component. Analysing the relative importance of each dimension will provide tourismmarketing managers with insights about whether to introduce more emotional appeals or more cognitive stimuli when communicating with their audiences.

Our results will also help both public administrations and tourism marketing managers to understand the image-formation process and design more efficient marketing strategies for tourism service websites. By understanding the relationships between future behavioural intentions and their antecedents, tourism managers will be better informed with respect to building an attractive image and improving their efficiency. Due to the great importance of the emotional component in our results, marketers should provide more emotional information to tourists involved in trip preparation, while also providing appropriate services during the vacation to satisfy the tourists' emotional side. Tourists will then perceive a good image of the service and be more likely to recommend it to other potential travellers.

Limitations and future research lines. The limitations of the study offer potential avenues for future research. First, we used online reviews from one single website and tourism service. This research methodology should be applied to other studies and tourist destinations in order to generalize the findings. Moreover, we analyzed how online reviews from the official destination site influences on the image of a tourist destination, but further research should be conducted to find out what results could be produced in other sites or platforms. It would be interesting to address other platforms 
different from the official destination site. For example, social networks such as Instagram or Facebook may also contribute to image creation and their impact on behavioral intentions should be addressed in future research. Second, taking into account the number of reviews and their valence should be of interest for subsequent studies. In our study, the comments were all mainly positive, but consumers seek to read both positive and negative reviews. While the number of positive reviews occupies a larger portion of total online reviews (Mulpuru et al., 2007), negative reviews are very influential (Chevalier \& Mayzlin, 2006). Third, the sample involved only undergraduate students, which represents a particular consumer segment from a Western-centric country. Although due to their homogeneity as compared to a sample chosen from the general population, they are considered ideal samples for testing theoretical predictions about the relationships among variables (Calder et al., 1981), which is in line with the purpose of this study; the results could be replicated with a sample comprised of real consumers (not only college students) to prove the generalizability of our findings.

\section{References}

Abubakar, A. M., and Ilkan, M. (2016), "Impact of online WOM on destination trust and intention to travel: A medical tourism perspective", Journal of Destination Marketing \& Management, Vol. 5 No. 3, pp.192-201.

Ahmed, Z.U. (1991), "Marketing your community: Correcting a Negative Image Some destinations have gained a negative image in the minds of travellers. Here are some marketing methods for offsetting a bad image-whether the reputation is deserved or not", Cornell Hotel and Restaurant Administration Quarterly, Vol. 31 No. 4, pp. 24-27.

Allen, C.T., Machleit, K.A., Kleine, S.S., and Notani, A.S. (2005), "A place for emotion in attitude models", Journal of Business Research, Vol. 58 No. 4, pp. 494-499.

Anderson, J.C., and Gerbing, D.W. (1988), "Structural equation modelling in practice: A review and recommended two-step approach", Psychological Bulletin, Vol. 103 No. 3, pp. 411-423.

Baloglu, S., and Brinberg, D. (1997), "Affective images of tourism destination”, Journal of Travel Research, Vol. 35 No. 4, pp. 11-15.

Baloglu, S., and McCleary, K.W. (1999), "A model of destination image formation”, Annals of Tourism Research, Vol. 26 No. 4, pp. 868-897. Batra, R., and Ahtola, O.T. (1991), "Measuring the hedonic and utilitarian sources of consumer attitudes", Marketing Letters, Vol. 2 No. 2, pp. 159-170.

Batra, R., and Ray, M.L. (1986), "Affective responses mediating acceptance of advertising", Journal of Consumer Research, Vol.13 No. 2, pp. 234-249.

Beerli, A., and Martin, D.J. (2004), "Factors influencing destination image”, Annals of Tourism Research, Vol. 31 No. 3, pp. 657-681.
Bentler, P.M. (2005), EQS (Version 6. 1).Structural equations program manual, Encino, CA: Multivariate Software, Inc.

Bigné, J.E., Mattila, A.S., and Andreu, L. (2008), "The impact of experiential consumption cognitions and emotions on behavioural intentions", Journal of Services Marketing, Vol. 22 No. 4, pp. 303-315.

Bigné, J.E., Sánchez, G.I., and Sanz, B.S. (2009), “The functionalpsychological continuum in the cognitive image of a destination: A confirmatory analysis", Tourism Management, Vol. 30 No. 5, pp. 715-723.

Bigné, J.E., Sanchez, M.I., and Sanchez, J. (2001), “Tourism image, evaluation variables and after purchase behaviour: inter-relationship", Tourism Management, Vol. 22 No. 6, pp. 607-616.

Blaney, P.H. (1986), "Affect and memory: a review", Psychological Bulletin, Vol. 99 No. 2, pp. 229-246.

Burke, M.C., and Edell, J.A. (1989), "The impact of feelings on adbased affect and cognition", Journal of Marketing Research, Vol. 26 No. 1, pp. 69-83.

Calantone, R.J., Benedetto, A.D., Hakam, A., and Bojanic, D.C. (1989), "Multiple multinational tourism positioning using correspondence analysis", Journal of Travel Research, Vol. 28 No. 2, pp. 25-32.

Calder, B.J., Phillips, L.W., and Tybout, A.M. (1981), "Designing research for application”, Journal of Consumer Research, Vol. 8 No. 2, pp. 197-207.

Campbell, M.C., and Keller, K.L. (2003), "Brand familiarity and advertising repetition effects", Journal of Consumer Research, Vol. 30 No. 2, pp. 292-304.

Camprubi, R., Guia, J., and Comas, J. (2014),'Analysing image fragmentation in promotional brochures a case study of two urban destinations", Journal of Hospitality and Tourism Research, Vol. 38 No. 2, pp. 135-161.

Casaló, L.V., Flavián, C., Guinalíu, M., and Ekinci, Y. (2015), “Avoiding the dark side of positive online consumer reviews: Enhancing reviews' usefulness for high risk-averse travellers", Journal of Business Research, Vol. 68 No. 9, pp. 1829-1835.

Chen, J.S. (2001), “A case study of Korean outbound travellers' destination images by using correspondence analysis", Tourism Management, Vol. 22 No. 4, pp. 345-350.

Chevalier, J.A., and Mayzlin, D. (2006), “The effect of word of mouth on sales: Online book reviews", Journal of Marketing Research, Vol. 43 No. 3, pp. 345-354.

Chong, A. Y. L., Khong, K. W., Ma, T., McCabe, S., \& Wang, Y. (2018), "Analyzing key influences of tourists' acceptance of online reviews in travel decisions", Internet Research, Vol. 28 No.3, pp. 564-586. 
Clubrural 2019. Barómetro del turismo rural en España. Primer semestre de 2019. available at: https://www.clubrural.com/barometroturismo-rural/barometro-turismo-rural-1-semestre-2019.pdf

Cohen, J.B., and Areni, C.S. (1991), "Affect and consumer behaviour", Handbook of consumer behaviour, Vol. 4 No. 7, pp. 188-240.

Coulter, K.S. (1998), "The effects of affective responses to media context on advertising evaluations", Journal of Advertising, Vol. 27 No. 4, pp. 41-51.

Cox, C., Burgess, S., Sellitto, C., and Buultjens, J. (2009), "The role of user-generated content in tourists' travel planning behaviour", Journal of Hospitality Marketing and Management, Vol. 18 No. 8, pp. 743-764.

Crompton, J.L. (1979), "An assessment of the image of Mexico as a vacation destination and the influence of geographical location upon that image", Journal of Travel Research, Vol. 14 No. 4, pp. 18-23.

Ekinci, Y., and Hosany, S. (2006), "Destination personality: An application of brand personality to tourism destinations", Journal of Travel Research, Vol 45, No 2, pp 127-139.

Fornell, C., and Larcker, D.F. (1981), "Evaluating structural equation models with unobservable variables and measurement error", Journal of Marketing Research, Vol.18 No. 1, pp. 39-50.

Gartner, W.C. (1993), "Image formation process", Journal of Travel and Tourism Marketing, Vol. 2 No. 2/3, pp.191-215.

Gilly, M.C., Graham, J.L., Wolfinbarger, M., and Yale, L.J. (1998), “A dyadic study of interpersonal information search", Journal of Academic Marketing Science, Vol. 26 No. 2, pp. 83-100.

Gretzel, U., and Yoo, K.H. (2008), Use and impact of online travel reviews, In: P. O'Connor, W. Höpken, U. Gretzel (eds.) Information and communication technologies in tourism (pp. 35-46). New York: Springer Verlag.

Hair, J.F., Anderson, R.E., Tatham, R.L., and Black, W.C. (1998), Multivariate analysis. Madrid: Prentice Hall.

Hajli, M.N. (2014), "A study of the impact of social media on consumers", International Journal of Market Research, Vol. 56 No. 3, pp. 388-404.

Hayes, A.F. (2009), "Beyond Baron and Kenny: Statistical mediation analysis in the new millennium”, Communication Monographs, Vol. 76 No. 4, pp. $408-420$.

Herrero, C.A., and San Martín, G.H. (2012), "Developing and testing a global model to explain the adoption of websites by users in rural tourism accommodations", International Journal of Hospitality Management, Vol. 31 No. 4, pp. 1178-1186.
Hidalgo-Alcázar, C., Sicilia, M., and Ruiz De Maya, S. (2015). "La imagen de un producto turístico rural a través del acceso al contenido generado por otros usuarios en internet: Diferencias por género", Journal of technology management \& innovation, Vol. 10 No.3, pp.75-84.

Holbrook, M.B., and Hirschman, E.C. (1982), “The experiential aspects of consumption: Consumer fantasies, feelings, and fun", Journal of Consumer Research, Vol. 9 No. 2, pp. 132-140.

Hosany, S., and D. Gilbert. (2010), "Measuring Tourists' Emotional Experiences toward Hedonic Holiday Destinations", Journal of Travel Research, Vol. 49 No. 4, pp. 513-526.

Hu, L., Bentler, P.M., and Kano, Y. (1992), "Can test statistics in covariance structure analysis be trusted?", Psychological Bulletin, Vol. 112 No. 2, pp. 351-362.

Jani, D., and Hwang, Y. (2011), "User-generated destination image through weblogs: A comparison of pre- and post-visit images", Asia Pacific Journal of Tourism Research, Vol. 16 No. 3, pp. 339-356.

Keh, H.T., and Pang, J. (2010), "Customer reactions to service separation”, Journal of Marketing, Vol. 74 No. 2, pp. 55-70.

Kim, H., and Richardson, S.L. (2003), "Motion picture impacts on destination images", Annals of Tourism Research, Vol. 30 No. 1, pp. 216-237.

Kim, J., and Gupta, P. (2012), "Emotional expressions in online user reviews: How they influence consumers' product evaluations", Journal of Business Research, Vol. 65 No. 7, pp. 985-992.

Kneesel, E., Baloglu, S., and Millar, M. (2010), "Gaming destination images: Implications for branding", Journal of Travel Research, Vol. 49 No. 1 , pp. $68-78$.

Lanfranchi, M., Giannetto, C., and De Pascale, A. (2014), "Rural tourism: A kind of sustainable tourism in the face of global economic crisis", International Journal for Responsible Tourism, Vol. 3 No. 2, pp. 15-28.

Lee, C., Lee, Y., and Lee, B. (2005), "Korea's destination image formed by the 2002 world cup", Annals of Tourism Research, Vol. 32 No. 4, pp. 839-858.

Lee, W., and Gretzel, U. (2012), "Designing persuasive destination websites: A mental imagery processing perspective", Tourism Management, Vol. 33 No. 5, pp. 1270-1280.

Leisen, B. (2001), "Image segmentation: the case of a tourism destination”, Journal of Services Marketing, Vol. 15 No. 1, pp. 49-66.

Lin, C.H., Morais, D.B., Kerstetter, D.L., and Hou, J.S. (2007), "Examining the role of cognitive and affective image in predicting choice across natural, developed, and theme-park destinations", Journal of Travel Research, Vol. 46 No. 2, pp. 183-194. 
Litvin, S.W., Goldsmith, R.E., and Pan, B. (2008), "Electronic wordof-mouth in hospitality and tourism management", Tourism management, Vol- 29 No. 3, pp. 458-468.

Liu, Q.B., Karahanna, E., and Watson, R.T. (2011), "Unveiling usergenerated content: Designing websites to best present customer reviews", Business Horizons, Vol. 54 No. 3, pp. 231-240.

Liu, Z., and Park, S. (2015), "What makes a useful online review? Implication for travel product websites”, Tourism Management, Vol. 47, pp. 140-151.

López, I., and Ruiz, S. (2011), "Explaining website effectiveness: The hedonic-utilitarian dual mediation hypothesis", Electronic Commerce Research and Applications, Vol. 10 No. 1, pp. 49-58.

López, I., Ruiz, S., and Sicilia, M. (2007), “Cómo medir emociones y pensamientos en los estudios sobre el comportamiento de los consumidores", Investigación y Marketing, Vol. 94, pp. 67-74.

Mackay, K.J., and Fesenmaier, D. (2000), "An exploration of cross-cultural destination image assessment", Journal of Travel Research, Vol. 38 No. 4 , pp. $417-423$.

Marinao, E., Chasco, C. and Torres, E. (2012), “Trust in tourist destinations. The role of local inhabitants and institutions", Academia. Revista Latinoamericana de Administración, No. 51, pp. 27-47.

Mattila, A.S., and Enz, C. A. (2002), "The role of emotions in service encounters", Journal of Service Research, Vol. 4, No. 4, pp. 268-277.

Mendes-Filho, L., Mills, A. M., Tan, F. B., and Milne, S. (2018), "Empowering the traveler: an examination of the impact of user-generated content on travel planning", Journal of Travel \& Tourism Marketing, Vol. 35 No. 4, pp. 425-436.

Mendes-Filho, L.A.M., Tan, F.B., and Mills, A. (2012), "User-generated content and travel planning: An application of the theory of planned behaviour", Revista Brasileira de Pesquisa em Turismo, Vol. 6 No. 3, pp. 280-289.

Moreno-Gil, S., and Martín-Santana, J.D. (2015), "Understanding the Image of Self-Contained and Serviced Apartments: The Case of Sun and Beach Destinations", Journal of Hospitality and Tourism Research, Vol. 39 No. 3, pp. 373-400.

Mulpuru, S., Johnson, C., and Wright, S. (2007), Which personalization tools work for ecommerce - and why. eBusiness, Channel and Product Management Professionals, Forrester Research.

Narangajavana, Y., Fiol, L. J. C., Tena, M. Á. M., Artola, R. M. R., and García, J. S. (2017), "The influence of social media in creating expectations. An empirical study for a tourist destination", Annals of Tourism Research, Vol. 65, pp. 60-70.

Ong, B.S., and Horbunluekit, S. (1997), “The impact of a Thai cultural show on Thailand's destination image", American Business Review, Vol. 15 No. 2, pp. 97-103.
Papadimitriou, D., Kaplanidou, K., and Apostolopoulou, A. (2018), "Destination image components and word-of-mouth intentions in urban tourism: A multigroup approach", Journal of Hospitality \& Tourism Research, Vol. 42 No. 4, pp. 503-527.

Papathanassis, A., and Knolle, F. (2011), "Exploring the adoption and processing of online holiday reviews: A grounded theory approach", Tourism Management, Vol. 32 No. 2, pp. 215-224.

Park, D.H., Lee, J., and Han, I. (2007), “The effect of on-line consumer reviews on consumer purchasing intention: The moderating role of involvement", International Journal of Electronic Commerce, Vol. 11 No. 4, pp. 125-148.

Pestana, M. H., Parreira, A., and Moutinho, L. (2019), "Motivations, emotions and satisfaction: The keys to a tourism destination choice", Journal of Destination Marketing \& Management.

Pham, M.T., Cohen, J.B., Pracejus, J.W., and Hughes, G.D. (2001), "Affect monitoring and the primacy of feelings", Journal of Consumer Research, Vol. 28 No. 2, pp. 167-184.

Pike, S., and Ryan, C. (2004), "Destination positioning analysis through a comparison of cognitive, affective, and conative perceptions", Journal of Travel Research, Vol. 42 No. 4, pp. 333-342.

Prayag, G., Hosany, S., and Odeh, K. (2013), “The role of tourists' emotional experiences and satisfaction in understanding behavioural intentions", Journal of Destination Marketing and Management, Vol. 2 No. 2, pp. 118-127.

Prayag, G., Hosany, S., Muskat, B., \& Del Chiappa, G. (2017), "Understanding the relationships between tourists' emotional experiences, perceived overall image, satisfaction, and intention to recommend", Journal of Travel Research, Vol. 55 No. 1, pp.41-54.

Preacher, K.J., and Hayes, A.F. (2008), "Asymptotic and resampling strategies for assessing and comparing indirect effects in multiple mediator models", Behaviour Research Methods, Vol. 40 No. 3, pp. 879-891.

Qu, H., Kim, L.H., and Im, H.H. (2011), "A model of destination branding: Integrating the concepts of the branding and destination image", Tourism Management, Vol. 32 No. 3, pp. 465-476.

Rose, R.L., Miniard, P.W., and Bhatla, S. (1990), "Brand cognitions as determinants of brand attitudes: The influence of measurement and processing involvement", Advances in Consumer Research, Vol. 17 No. 1, pp. 128-134.

Russel, J.A. (1980), “A circumplex model of affect", Journal of Personality and Social Psychology, Vol. 39 No. 6, pp. 1161-1178.

Satorra, A., and Bentler, P.M. (1988), Scaling corrections for chi-square statistics in covariance structure analysis. In: (pp. 308-313) Proceedings of the American Statistical Association, Vol. 1. Los Angeles: University of California, Department of Psychology. 
Sicilia, M., Ruiz, S., and Munuera, J.L. (2005), "Effects of interactivity in a web site: the moderating effect of need for cognition", Journal of Advertising, Vol. 34 No. 3, pp. 31-44.

Singh, S.N., Lessig, P.V., and Kim, D. (2000), "Does your ad have too many pictures?” Journal of Advertising Research, Vol. 40 No. 1, pp. $11-27$.

Sirgy, M.J., and Su. C. (2000), "Destination image, self-congruity, and travel behaviour: Toward an Integrative Model”, Journal of Travel Research, Vol. 38 No. 4, pp. 340-352.

Tripadvisor (2018). "About Trip Advisor", available at: http://www.tripadvisor.com/PressCenter-c6-About_Us.html

Verlegh, P.W., Ryu, G., Tuk, M.A., and Feick, L. (2013), "Receiver responses to rewarded referrals: The motive inferences framework", Journal of the Academy of Marketing Science, Vol. 41 No. 6, pp- 669-682.

Vermeulen, I.E., and Seegers, D. (2009), "Tried and tested: The impact of online hotel reviews on consumer consideration", Tourism Management, Vol. 30 No. 1, pp. 123-127.
Voss, K.E., Spangenberg, E.R., and Grohmann, B. (2003), "Measuring the hedonic and utilitarian dimensions of consumer attitude", Journal of Marketing Research, Vol. 40 No. 3, pp. 310-320.

Wang, C.Y., and Hsu, M.K. (2010), “The relationships of destination image, satisfaction, and behavioural intentions: An integrated model", Journal of Travel and Tourism Marketing, Vol. 27 No. 8, pp. 829-843.

Xiang, Z., Magnini, V. P., and Fesenmaier, D. R. (2015), “Information technology and consumer behavior in travel and tourism: Insights from travel planning using the internet", Journal of Retailing and Consumer Services, Vol. 22, pp. 244-249.

Ye, Q., Law, R., Gu, B., and Chen, W. (2011), “The influence of usergenerated content on traveler behavior: An empirical investigation on the effects of e-word-of-mouth to hotel online bookings", Computers in Human Behaviour, Vol. 27, pp. 634-639.

Zajonc, R.B. (1980), "Feeling and thinking: Preferences need no inferences”, American Psychologist, Vol. 35 No. 2, pp. 151-175.

Zhang, H., Fu. X., Cai. L.A., and Lu. L. (2014), "Destination image and tourist loyalty: A meta-analysis", Tourism Management, Vol. 40, pp. 213-223. 